\title{
THE PROBLEMS OF COMPOSITE INDEX NUMBERS OF SMART CITIES
}

\author{
Tamás Dusek ${ }^{20}$ \\ https://doi.org/10.31410/itema.2018.53
}

\begin{abstract}
Smart city initiatives, plans, missions have "mushroomed" in every continent in recent years. These projects want to apply the information technology for improving the efficiency and quality of local services and for providing new services for the inhabitants, visitors and the entrepreneurs of the settlements, or more safety, leisure and less pollution. Areas of applications are manifold, such as transportation (vehicle routing, road pricing, parking systems, traffic patterns, congestion reducement, smart traffic lights and so on), mobile workforce enablement (city surveyors, park maintenance, inspectors, health and social services), energy (street lighting, building control, demand for electricity, energy theft detection), utilities (smart meters, field service, customer service, maintenance optimization and so on), healthcare (reducement of waiting times, forecast of visit and admission rates, realtime alerting, telemedicine and so on), education, security and others.

These projects have mainly positive impact from technological point of view (for example, more information, quality improvement, more safety is engendered). However, in the evaluation of the projects, the cost benefit analysis, the comparison of implementation and maintenance costs and the realization of benefits is either missing or use doubtful, questionable nonmonetary categories for benefits. Moreover, it typically neglects the displacement effect and opportunity costs, therefore systematically biased toward greater positive impacts. The dominant rhetoric and propaganda is strongly influenced by the big information technology companies, which set its sights on local governments as a huge, untapped market.

The paper deals with the problem of creating composite index numbers for the evaluation of Smart city projects and for the comparison of "smartness" of cities. These composite indicators are popular tools of technocrats and bureaucrats, but the transformation of a multi-indicator system into a one-dimensional metric scale, in spite of the often use of a sophisticated mathematical technique, is a highly questionable practice.
\end{abstract}

Keywords: smart city, indicator analyses, multicriteria analyses, decision support tools, information technology

\section{INTRODUCTION}

$\mathrm{S}$ mart city became a key term or rather a buzzword in the city planning and city strategy literature, sometimes used parallel with digital city or intelligent city, in the same or similar meaning. The term is a fantastic marketing trick: everybody wants to be smart. Plethora of other phrases emphasize the technological side of the concept: telecity, urban cybernetics, informational city, knowledge-based city, wired city, virtual city, metered city, real-time city, smart urbanism and others. These terms, but most frequently the term smart city, are used by the researchers, planners, technocrats, public media, government administrators, politicians and IT (information technology) companies. In every continent, in every settlement size category, from the very small towns to the global megacities, more and more participants

\footnotetext{
${ }^{20}$ Széchenyi István University, Győr, Egyetem tér 1, Hungary
} 
want to use more and more information technology and digital solutions, preferably not by the expense of their own budget, but by the expense of some outer sources, for example, grants and supports of the central governments.

Smart city projects became popular research topics, supported by both the interested cities and IT companies. The proportion of corporate research is unusually high in the area. The materials of companies, published not only in company propaganda materials (biased, subjective product descriptions by the IBM, Cisco, SAP, Intel, ABB, Siemens, Ericsson, Dunlop, Fujitsu, Google, Huawei, Hitachi, Microsoft, Oracle, General Electric for example), but in academic journals too, is quite common. Similarly, biased governmental marketing materials are also very frequent. An important element in the success and rapid spread of smart city programs is that policy makers and practitioners could create new jobs for themselves as a service class for implementing smart city projects. The risk of the projects is low: there are some improvements in something, which can be demonstrated, with forgetting to mention the costs and the possible alternative use of resources.

As the popularity of smart city research is increasing, the "measurement" of "smartness" became also a popular research topic. This is in accordance with the demand of the planners and project financing institutions for the success indicators, and with the observable tendency of new and newest indicators for describing the settlements from the point of view of the quality of life, livability, creativity, environment, social capital, development and many other fashionable research aspects of modern societies. Today, the pure list of these indicators would be a very long reading. Networked Society Index (by the Ericson), Green City Index (Siemens), European Green Capital Award, Innovation Cities Index, Arcadis Sustainable Cities Index, European Energy Award are some examples, which have some connection to the smart cities. Other motivation for new indices is the publication possibilities: a new index (with a rotund naming) can be created and published with changing only a minor part of a previous index.

The abundance of these indicators creates a danger of the mechanistic, technocratic, superficial approach to the concerned questions, instead of a more critical, inclusive evaluation. Moreover, these composite or complex indicators join up extremely different basic indicators. The paper deals with this conceptual problem, after presenting some general question about the smart cities.

\section{TERMINOLOGY AND TYPICAL APPROACHES TO SMART CITY}

The term smart city has been variously defined within the literature, but can broadly be divided into two distinct but related understandings as to what makes a city smart. The first approach stresses on the technological elements: sensors, cameras, digitalization, big data, wireless technologies, applications, grids, buildings, infrastructures, networks system integration and so on. The second approach has an emphasis on the knowledge economy aspects, innovation and creativity. Local democracy, participation of citizens, quality of life plays also an important role in these definitions. The mix of the two approaches is also frequent, the stressing on synergies between new technology and social structure. These concepts are mainly positive, desirable, and attractive. As many authors point out, the term is brilliant from the marketing point of view: smartness is a more user-friendly, positive term than the more elitist term intelligent [1].

We do not want to give a new definition. Instead of this we collected some definitions, organized into Table 1, which shows the huge diversity. Most of the papers deal in the 
beginnings with the problem of the definition, moreover, there are papers, which deal only with this conceptual problem; see for example [2], [3], [4].

Table 1: Definitions of smart city

\begin{tabular}{|c|c|c|}
\hline Definition & Author(s) & Year \\
\hline $\begin{array}{l}\text { We believe a city to be smart when investments in human and } \\
\text { social capital and traditional (transport) and modern (ICT) } \\
\text { communication infrastructure fuel sustainable economic growth } \\
\text { and a high quality of life, with a wise management of natural } \\
\text { resources, through participatory governance. }\end{array}$ & $\begin{array}{l}\text { Caragliu, A.; } \\
\text { De Bo, C.; } \\
\text { Nijkamp, P. } \\
{[5]}\end{array}$ & 2011 \\
\hline $\begin{array}{l}\text { A smart city infuses information into its physical infrastructure to } \\
\text { improve conveniences, facilitate mobility, add efficiencies, } \\
\text { conserve energy, improve the quality of air and water, identify } \\
\text { problems and fix them quickly, recover rapidly from disasters, } \\
\text { collect data to make better decisions, deploy resources effectively, } \\
\text { and share data to enable collaboration across entities and domains. }\end{array}$ & $\begin{array}{l}\text { Nam, T.; } \\
\text { Pardo, T. A. } \\
{[1]}\end{array}$ & 2011 \\
\hline $\begin{array}{l}\text { A smart city is a well-defined geographical area, in which high } \\
\text { technologies such as ICT, logistic, energy production, and so on, } \\
\text { cooperate to create benefits for citizens in terms of well-being, } \\
\text { inclusion and participation, environmental quality, intelligent } \\
\text { development; it is governed by a well-defined pool of subjects, } \\
\text { able to state the rules and policy for the city government and } \\
\text { development. }\end{array}$ & $\begin{array}{l}\text { Dameri, R. P. } \\
{[6]}\end{array}$ & 2013 \\
\hline $\begin{array}{l}\text { Smart cities are presented as the object of a wide range of } \\
\text { technologically mediated practices of management at a distance, } \\
\text { based on orchestrated assemblages of computerized systems that } \\
\text { act as conduits for multiple crosscutting forms of data collection, } \\
\text { transfer, and analysis. At their core, efforts towards smart cities } \\
\text { thus imply a world of optimized ordering and regulation that relies } \\
\text { fundamentally on the coding of social life into software }\end{array}$ & $\begin{array}{l}\text { Klauser, F.; } \\
\text { Paasche, T.; } \\
\text { Söderström, } \\
\text { O. [7] }\end{array}$ & 2012 \\
\hline $\begin{array}{l}\text { Smart City is the product of Digital City combined with the Internet } \\
\text { of Things. }\end{array}$ & $\begin{array}{l}\mathrm{Su}, \mathrm{K} . ; \mathrm{Li}, \mathrm{J} . \\
\mathrm{Fu}, \mathrm{H} .[8]\end{array}$ & 2011 \\
\hline $\begin{array}{l}\text { A city that monitors and integrates conditions of all of its critical } \\
\text { infrastructures, including roads, bridges, tunnels, rails, subways, } \\
\text { airports, seaports, communications, water, power, even major } \\
\text { buildings, can better optimize its resources, plan its preventive } \\
\text { maintenance activities, and monitor security aspects } \\
\text { while maximizing services to its citizens }\end{array}$ & Hall, P. [9] & 2000 \\
\hline $\begin{array}{l}\text { Two main streams of research ideas: 1) smart cities should do } \\
\text { everything related to governance and economy using new thinking } \\
\text { paradigms and 2) smart cities are all about networks of sensors, } \\
\text { smart devices, real-time data, and ICT integration in every aspect } \\
\text { of human life. }\end{array}$ & $\begin{array}{l}\text { Cretu, G. L. } \\
{[10]}\end{array}$ & 2012 \\
\hline $\begin{array}{l}\text { A Smart City is a city well performing in a forward-looking way in } \\
{[\ldots] \text { six characteristics }[\ldots] \text {, built on the smart combination of }} \\
\text { endowments and activities of self-decisive, independent and aware } \\
\text { citizens. }\end{array}$ & $\begin{array}{l}\text { Giffinger, } \mathrm{R} \text {. } \\
{[11]}\end{array}$ & 2007 \\
\hline $\begin{array}{l}\text { 'Smart city' seems like a textbook example of an 'empty signifier' } \\
\text { in urban planning; that is, a concept virtually void of any substantive } \\
\text { meaning. }\end{array}$ & $\begin{array}{l}\text { Haarstad, H. } \\
{[12]}\end{array}$ & 2017 \\
\hline
\end{tabular}


From technological point of view, the approach toward smart cities lies on a scale of which one endpoint is the techno-utopian vision, the optimistic view of future, where all problems are solved by the help of technology. Sustainability, energy efficiency, infrastructure optimization, quality of life, social initiatives, e-government safety, security, intelligence, and citizens are keywords in this enthusiastic literature. The other extremists have an anti-technology attitude; Smart city for them is equal with control of the society by the authorities and greedy corporations [13], [14]. The starting point of both supporters and critics is often not the normal experiences of "ordinary" towns and cities, but the planned or semi-finished Greenfield megaprojects of IT multinationals financed by the government (see some of them in Table 2), or the high-tech islands of megacities (such as Sao Paulo, Kuala Lumpur, Singapore).

Table 2: Planned or semi-finished megaprojects, smart city islands

\begin{tabular}{|c|c|}
\hline City & Country \\
\hline Songdo & South Korea \\
\hline Masdar & United Arab Emirates \\
\hline Living PlanIT & Portugal \\
\hline Konza Technology City & Kenya \\
\hline Cyberjaya & Malaysia \\
\hline Putrajaya & Malaysia \\
\hline Palava & India \\
\hline Smart City Kochi & India \\
\hline Wave Smart City & India \\
\hline Meixi & China \\
\hline SmartCity Malta & Malta \\
\hline
\end{tabular}

\section{INDIVIDUAL AND COMPLEX INDICATORS OF SMART CITIES}

Lots of complex indicators were suggested for the measuring of smartness of the cities (see for example [11]; [15]; [16]; [17]; [18]). Complex indicators are always based on basic indicators. The numbers of basic indicators merged into a complex indicator can be only a few (less than 10 ) or very large (more than 100). The surprising or strange feature of the basic indicators of complex smart city indicators is that vast majority of them have nothing to do with information technology solutions, but they are very simple traditional indicators. Some examples from various proposed smart city indices:

- GDP per capita,

- GDP growth,

- Unemployment rate,

- Ratio of deaths per 100000 inhabitants,

- Average working hours per year of worker,

- Net annual income,

- Number of headquarters on Forbes,

- Average rent prices for local households,

- Average years of schooling of inhabitants,

- Adult illiteracy rate,

- Population density,

- Ratio of female workers in the public administration,

- Number of public and private hospitals and health centers per city,

- Number of museums,

- Crime rate, 
- Vehicle per person,

- Poverty ratio,

- Road traffic deaths,

- Deaths due to the cardiovascular diseases,

- Water consumption,

- Households without electricity supply service,

- Greenhouse gas emissions per capita,

- Green spaces per person,

- Waste generated per person,

- Ethnic plurality.

This list of traditional indicators, used as a "smart city" indicator, could be enlarged. Several indicators are conceptually problematic: higher value or lower value of the indicator is advantageous? What is the case, for example, with the population density, road density, ethnic plurality, female workers ratio? Other indicators have a clear meaning from the point of view of positivity, for example, lower unemployment rate or lower illiteracy is better than higher, but in which way is these indicators are connected to the information technology? These are traditional indicators, describing the development or economic situation of settlements, regions or countries.

The very different indicators could be good for the general or specific description of settlements. However, it is no sense to put together and merge the entirely different characteristics into one singular number, because the various original important information disappears in the complex indicators. These indicators do not create new information but either show the same as the original indicators or rather disturb the transparency.

\section{Funding}

The research was supported by EFOP3.6.1-16-2016-00017 project.

\section{REFERENCES}

[1] Nam, T., Pardo, T. A. (2011) Conceptualizing Smart City with Dimensions of Technology, People, and Institutions. Proc. $12^{\text {th }}$ Conference on Digital Government Research, College Park, MD, June 12-15, 2011

[2] Allwinkle, S., Cruickshank, P. (2011) Creating smarter cities: an overview. Journal of Urban Technology, 18, 2, pp. 1-16

[3] Albino, V., Berardi, U., Dangelico, R. M. (2015) Smart Cities: Definitions, Dimensions, Performance, and Initiatives. Journal of Urban Technology, 22, 1, pp. 3-21.

[4] Mora, L., Bolici, R., Deakin, M. (2017) The first two decades of smart-city research: a bibliometric analysis. Journal of Urban Technology, 24, 1, pp. 2-27.

[5] Caragliu, A., De Bo, C., Nijkamp, P. (2011) Smart cities in Europe. Journal of Urban Technology, 18, 2, pp. 65-82.

[6] Dameri, R. P. (2013) Searching for Smart City definition: a comprehensive proposal. International Journal of Computers \& Technology, 11, 5. pp. 2544-2551.

[7] Klauser, F., Paasche, T., Söderström, O. (2014) Michel Foucault and the smart city: power dynamics inherent in contemporary governing through code. Environment and Planning D: Society and Space, 32, pp. 869-885.

[8] Su, K., Li, J., Fu, H. (2011) Smart City and the applications. IEEE International Conference on Electronics, Communications and Control (ICECC), pp. 1028-1031. 
[9] Hall, P. (2000) Creative cities and economic development. Urban Studies, 37, 4, pp. $633-$ 649.

[10] Cretu, G. L. (2012) Smart Cities Design Using Event-driven Paradigm and Semantic Web. Informatica Economica, 16, 4, pp. 57-67

[11] Giffinger, R. (2007) Smart Cities: Ranking of European medium-sized cities. Centre of Regional Science, Vienna

[12] Haarstad, H. (2017) Constructing the sustainable city: examining the role of sustainability in the smart city discourse. Journal of Environmental Policy \& Planing, 19, 4, pp. 423437.

[13] Greenfield, A. (2013) Against the Smart City. New York: Do Projects.

[14] Krivy, M. (2018) Towards a critique of cybernetic urbanism: The smart city and the society of control. Planning Theory, 17, 1, pp. 8-30

[15] Zygiaris, S. (2013) Smart City Reference Model: Assisting Planners to Conceptualize the Building of Smart City Innovation Ecosystems. Journal of the Knowledge Economy, 4, 2, pp. 217-231.

[16] Lazaroiu, G. C., Roscia, M. (2012) Definition Methodology for the Smart Cities Model. Energy, 47, 1. pp. 326-332.

[17] Lombardi, P., Giordano, S., Farouh, H., Yousef, W. (2012) Modeling the Smart City Performance. Innovation: The European Journal of Social Science Research, 25, 2, pp. 137-149.

[18] Carli, R., Dotoli, M., Pellegrino, R., Ranieri, L. (2013) Measuring and Managing the Smartness of Cities: A Framework for Classifying Performance Indicators. Proceedings of IEEE Systems, Man, and Cybernetics, 2013. 